\title{
PENGARUH KOMPETENSI SUMBER DAYA MANUSIA, PENERAPAN STANDAR AKUNTANSI PEMERINTAHAN, DAN PENERAPAN SISTEM AKUNTANSI KEUANGAN DAERAH TERHADAP KUALITAS LAPORAN KEUANGAN PEMERINTAH DAERAH PROVINSI DIY
}

\author{
Putriasri Pujanira \\ Prodi Akuntansi Universitas Negeri Yogyakarta \\ nirapuja@gmail.com \\ Abdullah Taman \\ Staf Pengajar Jurusan Pendidikan Akuntansi Universitas Negeri Yogyakarta
}

\begin{abstract}
Abstrak: Pengaruh Kompetensi Sumber Daya Manusia, Penerapan Standar Akuntansi Pemerintahan, dan Penerapan Sistem Akuntansi Keuangan Daerah terhadap Kualitas Laporan Keuangan Pemerintah Daerah Provinsi DIY. Penelitian ini bertujuan untuk mengetahui pengaruh Kompetensi Sumber Daya Manusia, Penerapan Standar Akuntansi Pemerintahan, dan Penerapan Sistem Akuntansi Keuangan Daerah secara bersama-sama, berpengaruh serhadap Kualitas Laporan Keuangan Pemerintah Daerah.. Populasi dalam penelitian ini adalah 15 Dinas-dinas Daerah Pemerintah Daerah DIY. Teknik pengumpulan data dengan kuesioner kepada 120 responden pegawai penatausaha keuangan. Berdasarkan hasil penelitian: (1) Kompetensi Sumber Daya Manusia berpengaruh positif terhadap Kualitas Laporan Keuangan Pemerintah Daerah ditunjukkan dengan t hitung = 8,049 dan $r^{2}{ }_{x_{1} y}=0,388$, (2)Penerapan Standar Akuntansi Pemerintahan berpengaruh positif terhadap Kualitas Laporan Keuangan Pemerintah Daerah ditunjukkan dengan $t$ hitung $=6,071$ dan $r^{2}{ }_{x_{2} y}=0,265$, (3)Penerapan Sistem Akuntansi Keuangan Daerah berpengaruh postif terhadap Kualitas Laporan Keuangan Pemerintah Daerah ditunjukkan dengan t hitung = 5,949 dan $r_{x_{3} y}^{2}=0,258$, (4)Kompetensi Sumber Daya Manusia, Penerapan Standar Akuntansi Pemerintahan, dan Penerapan Sistem Akuntansi Keuangan Daerah secara bersama-sama berpengaruh positif terhadap Kualitas Laporan Keuangan Pemerintah Daerah DIY ditunjukkan dengan persamaan regresi, $F$ hitung $=23,133$ dan $\mathrm{R}_{\mathrm{y}(1,2,3)}^{2}=0,410$.
\end{abstract}

Kata Kunci: Kualitas Laporan Keuangan Pemerintah Daerah, Kompetensi Sumber Daya Manusia Standar Akuntansi Pemerintahan, Sistem Akuntansi Keuangan Daerah.

Abstract: The Influence of Human Resource Competency, Application of Governmental Accounting Standard, Application Region's Financial Accounting System on Quality of Region's Financial Statement. The aims of this research is to describe the influence of human resource competency, application of governmental accounting standard, application region's financial accounting system on quality of region's financial statement. The population of this research is 15 Departements in Local Goverment DIY. Data collection technique used questionnaire to 120 respondent. The result showed that: (1)There is a positive influence of human resource competency on quality of region's financial statement indicated by $t$ value $=8,049$ and $r^{2}{ }_{x_{1} y}=0,388$, (2) There is a positive influence of application of governmental accounting standard on quality of region's financial statement indicated by t value $=6,071$ and $\mathrm{r}_{\mathrm{x}_{2} \mathrm{y}}^{2}=0,265$, (3) There is a positive influence of application region's financial system on quality of region's financial statement indicated by $t$ value $=5,949$ and $\mathrm{r}^{2}{ }_{\mathrm{x}_{3} \mathrm{y}}=0,258$, (4) human resource competency, application of governmental accounting standard, region's financial accounting system had a positive effect on quality of financial statement indicated by $F$ value $=23,133$ and also $R_{y\left(x_{1}, x_{2}, x_{3}\right)}^{2}=0,410$.

Keywords : Quality Of Region's Financial Statement, Human Resource Competency, Application Of Governmental Accounting Standard, Application Region's Financial Accounting System. 


\section{JURNAL NOMINAL / VOLUME VI NOMOR 2 / TAHUN 2017}

\section{PENDAHULUAN}

Pengelolaan keuangan daerah dituntut untuk tertib, transparan, dan akuntabel guna mewujudkan pemerintahan yang bersih. Salah satu upaya mewujudkan pemerintahan yang bersih maka pemerintah daerah diwajibkan untuk menyusun Laporan Keuangan Pemerintah Daerah. Laporan keuangan tersebut setidaktidaknya berupa Laporan Realisasi Anggaran, Neraca, Laporan Arus Kas dan Catatan atas Laporan Keuangan, Laporan Keuangan yang berkualitas dapat memberikan manfaat dalam upaya mengambil kebijakan suatu pemerintahan di masa yang akan datang. Laporan keuangan berkualitas dapat dilihat dari opini dari Badan Pemeriksa Keuangan. Ada strata penilaian laporan keuangan dari hasil pemeriksaan yang dilakukan Badan Pemeriksa Keuangan. Hasil audit berupa opini dari Badan Pemeriksa Keuangan yang merupakan strata tertinggi adalah Wajar Tanpa Pengecualian (WTP) kemudian selanjutnya adalah Wajar Dengan Pengecualian (WDP), Tidak Wajar (TW), dan Tidak Menyatakan Pendapat (TMP). Selain opini dari Badan Pemeriksa Keuangan, Kualitas Laporan Keuangan dapat dilihat juga apabila telah disusun sesuai dengan Standar Akuntansi Pemerintahan (SAP), disusun melalui sistem akuntansi pemerintah daerah, informasi keuangan tidak terdapat penyimpangan dari peraturan perundang- undangan, dan disajikan secara tepat waktu sesuai dengan peraturan perundangundangan.

Fenomena yang terjadi dalam laporan hasil pemeriksaan Badan Pemeriksa Keuangan (BPK) sepanjang semester I2016 untuk tahun pelaporan 2015, Badan Pemeriksa Keuangan (BPK) mencatat masih banyak laporan keuangan pemerintah daerah (LKPD) yang belum memperoleh opini wajar tanpa pengecualian (WTP). Dalam LKPD 2015, tercatat hanya 58 persen atau 312 LKPD yang memperoleh opini WTP. Sementara itu, LKPD lainnya tercatat memperoleh opini lain yaitu Wajar dengan Pengecualian (WDP) tercatat ada 187 LKPD, Tidak Menyatakan Pendapat (TMP) 30, dan Tidak Wajar (TW) empat LKPD. Badan Pemeriksa Keuangan juga mengungkapkan 10.198 temuan yang memuat 15.568 permasalahan. Sebanyak 51 persen permasalahan adalah ketidakpatuhan terhadap ketentuan peraturan perundangundangan. Ketidakpatuhan tersebut berkaitan dengan penyerahan laporan keuangan pemerintah daerah yang tidak tepat waktu.

Kompetensi sumber daya manusia penting dalam mengelola dan menyajikan informasi keuangan sehingga laporan keuangan yang disusun dapat tepat waktu. Selain sumber daya manusia yang kompeten, penerapan Standar Akuntansi Pemerintahan juga memiliki pengaruh terhadap Kualitas Laporan Keuangan. 


\section{JURNAL NOMINAL / VOLUME VI NOMOR 2 / TAHUN 2017}

Instansi pemerintah mulai tahun 2015 harus menyusun Laporan Keuangan Pemerintah Daerah (LKPD) sesuai dengan Standar Akuntansi Pemerintahan yaitu berbasis akrual. Laporan keuangan yang sesuai dengan Standar Akuntansi yang berbasis akrual membutuhkan sistem akuntansi. Penerapan Sistem Akuntansi Keuangan Daerah dibutuhkan dalam mengelola informasi akuntansi. Hal ini disebabkan karena pada dasarnya Sistem Akuntansi Keuangan Daerah mampu memberikan output data berupa laporan keuangan pemerintah daerah.

Tahun Anggaran (TA) 2015 Laporan Keuangan Pemerintah Daerah DIY mendapat opini Wajar Tanpa Pengecualian (WTP) oleh Badan Pemeriksa Keuangan (BPK) DIY, pada Sidang Paripurna Istimewa DPRD DIY. Walau sudah kali keenam mengantongi opini WTP, laporan keuangan pemerinah daerah DIY masih terdapat catatan dari Badan Pemeriksa Keuangan. Salah satu catatan yang diberikan adalah masih belum tepatnya pencatatan aset-aset daerah DIY. Banyak aset milik Pemerintah daerah DIY yang belum jelas statusnya seperti beberapa bangunan Pemerintah Daerah DIY yang berdiri diatas Sultan Ground. Kepala Badan Kepegawaian Daerah (BKD) DIY, Agus Supriyanto juga memaparkan bahwa Pegawai Negeri Sipil di lingkungan Pemerintah Derah DIY masih belum memenuhi kompetensi sebesar 40 persen (tribunjogja.com, 2016).

Masalah kompetensi sumber daya manusia menjadi tantangan setiap pegawai bidang keuangan dinas daerah Provinsi DIY. Fenomena yang dijumpai masih ditemukan kesenjangan antara kompetensi sebagai syarat tugas pokok dengan kompetensi yang dimiiki pegawai. Harus diakui masih ada permasalahan yang terjadi dimana staf pengelola keuangan dan penyusunan laporan keuangan yang terlibat dalam pengelolaan keuangan masih kurang memiliki keterampilan dalam bidang akuntansi. Berdasarkan uraian diatas, peneliti mengambil judul "Pengaruh Kompetensi Sumber Daya Manusia, Penerapan Standar Akuntansi Pemerintah, dan Penerapan Sistem Akuntansi Keuangan Daerah Terhadap Kualitas Laporan Keuangan Pemerintah Daerah Provinsi DIY”.

\section{METODE PENELITIAN}

Tempat dan Waktu Penelitian

Penelitian dilaksanakan di Pemerintah Daerah Provinsi DIY. Responden dalam penelitian adalah pegawai Bagian Keuangan 15 Dinas Pemerintah Daerah Provinsi DIY. Waktu penelitian pada bulan April 2017.

\section{Desain Penelitian}

Penelitian ini menggunakan penelitian kausal komparatif dengan metode survey. Penelitian kausal komparatif merupakan penelitian dengan 


\section{JURNAL NOMINAL / VOLUME VI NOMOR 2 / TAHUN 2017}

karakteristik masalah berupa hubungan sebab-akibat antara dua variabel atau lebih. Jenis data dalam penelitian ini adalah kuantitatif.Sumber data dalam penelitian ini adalah sumber data primer.

\section{Populasi}

Populasi dalam penelitian ini adalah seluruh pegawai penatausaha keuangan 15 Dinas Pemerintah Daerah Provinsi DIY. Jumlah populasi dalam penelitian ini adalah 120 responden. Subjek penelitian ini berjumlah 120 responden, maka penelitian ini bersifat populatif.

\section{Teknik Pengumpulan Data}

Penelitian ini menggunakan teknik pengumpulan data dengan kuesioner. Jenis angket dalam penelitian yaitu angket tertutup, di mana responden hanya memberi jawaban sesuai dengan apa yang sudah disediakan oleh peneliti, alternatif jawaban sudah tersedia.

\section{Instrumen Penelitian}

Instrumen penelitian adalah alat yang digunakan untuk mengukur fenomena yang diamati (Sugiyono, 2011:102). Teknik skala pengukuran instrumen dalam penelitian ini menggunakan skala Likert.

Tabel 1. Skor Skala Likert

\begin{tabular}{ccc}
\hline Jawaban & $\begin{array}{c}\text { Pernyataan } \\
\text { Positif }\end{array}$ & $\begin{array}{c}\text { Pernyataan } \\
\text { Negatif }\end{array}$ \\
\hline $\begin{array}{c}\text { Sangat Setuju } \\
\text { (SS) }\end{array}$ & 4 & 1 \\
\hline Setuju (S) & 3 & 2 \\
\hline $\begin{array}{c}\text { Tidak Setuju } \\
\text { (TS) }\end{array}$ & 2 & 3 \\
\hline $\begin{array}{c}\text { Sangat Tidak } \\
\text { Setuju (STS) }\end{array}$ & 1 & 4 \\
\hline
\end{tabular}

\section{Uji Coba Instrumen}

Uji coba instrumen yang digunakan dalam penelitian ini adalah uji coba terpakai. Uji instrumen dilaksanakan pada bulan April 2017, dengan seluruh anggota populasi sebagai responden. Uji coba instrumen terdiri dari uji validitas data dan uji reliabilitas data. Uji validitas menggunakan rumus korelasi Product Moment dari Pearson Correlation, yaitu:

$$
\mathrm{r}=\frac{N(\Sigma x y)-(\Sigma x)(\Sigma \mathrm{y})}{\sqrt{\left\{\left(N \Sigma x^{2}\right)-\left(\Sigma x^{2}\right)\right\}\left\{\left(N \Sigma y^{2}\right)-\left(\Sigma y^{2}\right)\right\}}}
$$

Berdasarkan hasil uji validitas diketahui variabel Kualitas Laporan Keuangan terdapat dua pernyataan yang tidak valid yaitu pernyataan nomor 1 dan 3 . Pada butir pernyataan variabel Kompetensi Sumber Daya Manusia terdapat dua pernyataan yang tidak valid yaitu pernyataan nomor 23 dan 24. Pada butir pernyataan variabel Penerapan Standar Akuntansi Pemerintahan terdapat satu pernyataan yang tidak valid yaitu pernyataan nomor 4. Butir pernyataan variabel Penerapan Sistem Akuntansi Keuangan Daerah terdapat satu pernyataan yang tidak valid yaitu pernyataan nomor 14 . Uji reliabilitas data dilakukan dengan rumus Cronbach's Alpha sebagai berikut:

$$
r_{11}=\left(\frac{k}{k-1}\right)\left(1-\frac{\Sigma \sigma^{2} b}{\sigma^{2} t}\right)
$$




\section{JURNAL NOMINAL / VOLUME VI NOMOR 2 / TAHUN 2017}

Berdasarkan hasil uji reliabilitas dapat diketahui bahwa instrumen pada variabel Kualitas Laporan Keuangan Pemerintah Daerah (0,935) Kompetensi Sumber Daya Manusia $(0,980)$, Penerapan Standar Akuntansi Pemerintahan $(0,977)$, Penerapan Sistem Akuntansi Keuangan Daerah $(0,987)$ nilai Cronbach's Alpha berada di antara $0,9 \leq \mathrm{rh}<1$ dapat disimpulkan bahwa masing-masing variabel dinyatakan reliabel.

\section{Teknik Analisis Data}

\section{Analisis Deskriptif}

Analisis statistik deskriptif berfungsi untuk memberi gambaran atas objek yang diteliti melalui data populasi tanpa analisis dan membuat kesimpulan yang berlaku (Sugiyono, 2012: 29). Analisis deskriptif digunakan untuk menggambarkan rata-rata, median, modus, standar deviasi, nilai maksimal, minimal, dan jumlah data penelitian.

\section{Uji Asumsi Klasik}

Uji asumsi klasik dalam penelitian ini, dilakukan agar model regresi signifikan dan representatif. Uji asumsi klasik dalam penelitian ini terdiri dari uji linearitas, multikolinearitas, dan heteroskedastisitas.

Hubungan antar variabel dapat dikatakan linear apabila nilai signifikansi $>0,05$. Sebaliknya, jika nilai signifikansi $<0,05$, maka menunjukkan bahwa hubungan antar variabel tidak linear.

Uji multikolinearitas dapat dilihat dari Variance Inflation Factor (VIF) dan
Tolerance Value. Nilai tolerance yang rendah sama dengan nilai VIF yang tinggi. Jika nilai $\mathrm{VIF} \leq 10$ dan nilai Tolerence $\geq$ 0,10 menunjukkan tidak terdapat muktikolinieritas dalam penelitian tersebut.

$$
V I F=\frac{1}{\text { Tolerance Value }}
$$

Uji heteroskedastisitas menggunakan analisis dengan uji glesjer. Model regresi yang baik tidak terjadi heteroskedastisitas. Tidak terjadinya heteroskedastisitas dapat dilihat apabila probabilitas signifikasinya di atas tingkat kepercayaan 5\%.

$$
|\mathrm{Ut}|=\alpha+\beta \mathrm{Xt}+\mathrm{vt}
$$

\section{Uji Hipotesis}

Pengujian terhadap hipotesis yang digunakan dengan rumus analisis regresi sederhana untuk mengetahui pengaruh variabel bebas terhadap variabel terikat dan analisis regresi berganda untuk mengetahui pengaruh variabel bebas, secara bersamasama terhadap variabel terikat. Langkahlangkah dalam analisis regresi linear sederhana antara lain:

1) Membuat garis linear sederhana

$$
Y^{\prime}=a+b X
$$

2) Mencari koefisien korelasi (r)

$$
r_{x y}=\frac{\sum x y}{\sqrt{\left(\sum x^{2}\right)\left(\sum y^{2}\right)}}
$$

3) Mencari koefisien determinasi $\left(\mathrm{r}^{2}\right)$

$$
\mathrm{r}_{\mathrm{xy}}^{2}=\frac{\sum x y^{2}}{\left(\sum x^{2}\right)\left(\sum y^{2}\right)}
$$

4) Uji t

$$
\mathrm{t}=\frac{r(\sqrt{n-2}}{\sqrt{1-r^{2}}}
$$


JURNAL NOMINAL / VOLUME VI NOMOR 2 / TAHUN 2017

Apabila thitung lebih besar atau sama dengan $\mathrm{t}$ tabel berarti terdapat pengaruh antara variabel bebas dengan variabel terikat secara individual, hal ini dapat disimpulkan bahwa hipotesis yang diajukan diterima. Sebaliknya apabila t hitung lebih kecil dari t tabel berarti tidak ada pengaruh antara variabel bebas terhadap variabel terikat secara individual dan hipotesis ditolak.

Adapun analisis regresi berganda digunakan untuk mengetahui pengaruh variabel bebas, secara bersama-sama, terhadap variabel terikat. Langkahlangkahnya adalah sebagai berikut:

1) Membuat persamaan garis dengan tiga prediktor

$$
Y=a+b_{1} X_{1}+b_{2} X_{2}+b_{3} X_{3}
$$

2) Mencari koefisien determinasi (R) $\operatorname{antara} X_{1}, X_{2}$, dan $X_{3}$

$$
R_{y(1,2,3)} \sqrt{\frac{a_{1 \sum X_{2} y}+a_{2 \sum X_{2} y}+a_{3 \sum X_{3} y}}{\Sigma Y^{2}}}
$$

3) Mencari koefisien determinasi $\left(\mathrm{R}^{2}\right)$ $\operatorname{antara} \mathrm{X}_{1}, \mathrm{X}_{2}$, dan $\mathrm{X}_{3}$

$$
R_{y}^{2}\left(x_{1,} x_{2}, x_{3}\right)=\frac{\left(a_{1} \sum X_{1} Y+a_{2} \sum X_{2} Y+a_{3} \sum X_{3} Y\right)}{\sum Y^{2}}
$$

4) Uji F

$$
F_{\text {reg }}=\frac{r^{2}(N-m-1)}{m\left(1-r^{2}\right)}
$$

Pengambilan keputusan, nilai $\mathrm{F}$ hitung ini dikonsultasikan dengan nilai $\mathrm{F}$ tabel Jika F hitung sama dengan atau lebih besar dari $\mathrm{F}$ tabel, maka hipotesis diterima dengan kata lain variabel bebas secara bersama-sama berpengaruh terhadap variabel terikat. Sebaliknya, jika F hitung lebih kecil dari $\mathrm{F}$ tabel, maka hipotesis alternatif ditolak dengan kata lain variabel bebas secara bersama-sama tidak berpengaruh terhadap variabel terikat

\section{HASIL PENELITIAN DAN \\ PEMBAHASAN}

\section{Statistik Deskriptif}

Analisis data statistik deskriptif yang disajikan dalam penelitian ini meliputi Minimal, Maksimal, Mean, dan Standar

\begin{tabular}{|c|c|c|c|c|c|}
\hline Variabel & $\mathbf{N}$ & $\underset{\mathbf{n}}{\mathbf{M i}}$ & $\begin{array}{c}\mathbf{M a} \\
\mathbf{x}\end{array}$ & Mean & SD \\
\hline $\begin{array}{l}\text { Kualitas } \\
\text { Laporan } \\
\text { Keuangan }\end{array}$ & 104 & 23 & 36 & 30,23 & 3,43 \\
\hline $\begin{array}{l}\text { Kompetensi } \\
\text { Sumber } \\
\text { Daya } \\
\text { Manusia }\end{array}$ & 104 & 60 & 100 & 78,34 & 8,69 \\
\hline $\begin{array}{l}\text { Penerapan } \\
\text { Standar } \\
\text { Akuntansi } \\
\text { Pemerintah } \\
\text { an }\end{array}$ & 104 & 72 & 108 & 84,58 & 8,59 \\
\hline $\begin{array}{l}\text { Penerapan } \\
\text { Sistem } \\
\text { Akuntansi } \\
\text { Keuangan } \\
\text { Daerah }\end{array}$ & 104 & 72 & 100 & 80,42 & 7,72 \\
\hline
\end{tabular}
Deviasi (SD). Berikut adalah hasil analisis statistik deskriptif dari data penelitian:

Tabel 2.Hasil Analisis Deskriptif

\section{Hasil Analisis Data}

\section{Uji Asumsi Klasik}

Uji Asumsi Klasik terdiri dari uji linieritas, multikolinieritas, dan heteroskedastisitas. Hasil pengujian dapat dilihat pada tabel berikut : 
JURNAL NOMINAL / VOLUME VI NOMOR 2 / TAHUN 2017

Tabel 3. Hasil Uji Linieritas

\begin{tabular}{lcc}
\hline \multicolumn{1}{c}{ Variabel } & Linierity & Keterangan \\
\hline $\begin{array}{l}\text { Kompetensi Sumber } \\
\text { Daya Manusia }\end{array}$ & 0,076 & Linier \\
\hline $\begin{array}{l}\text { Penerapan Standar } \\
\text { Akuntansi } \\
\text { Pemerintahan }\end{array}$ & 0,661 & Linier \\
\hline $\begin{array}{l}\text { Penerapan Sistem } \\
\text { Akuntansi } \\
\text { Keuangan Daerah }\end{array}$ & 0,918 & Linier \\
\hline \multicolumn{2}{l}{ Sumber: Data Primer yang Diolah, 2017}
\end{tabular}

Tabel di atas menunjukkan bahwa Linierity untuk masing-masing variabel terhadap variabel dependen memiliki nilai signifikansi lebih dari nilai probabilitas 0,05. Oleh karena itu, dapat disimpulkan bahwa masing-masing variabel independen dengan variabel dependen dinyatakan linier.

Uji multikolinieritas bertujuan untuk mengetahui apakah dalam model regresi ditemukan adanya multikolinieritas antar variabel independen. Hasil pengujian multikolinieritas dapat dilihat pada tabel berikut:

Tabel 4. Hasil Uji Multikolinieritas

\begin{tabular}{cccc}
\hline Variabel & Tolerance & VIF & Keterangan \\
\hline $\begin{array}{c}\text { Kompetensi } \\
\text { Sumber Daya } \\
\text { Manusia }\end{array}$ & 0,495 & 2,018 & $\begin{array}{c}\text { Tidak terjadi } \\
\text { multikolinieritas }\end{array}$ \\
\hline $\begin{array}{c}\text { Penerapan } \\
\text { Standar }\end{array}$ & 0,254 & 3,933 & \\
Akuntansi & & & $\begin{array}{c}\text { Tidak terjadi } \\
\text { multikolinieritas }\end{array}$ \\
$\begin{array}{c}\text { Pemerintahan } \\
\text { Penerapan }\end{array}$ & & & \\
\hline $\begin{array}{c}\text { Sistem } \\
\text { Akuntansi } \\
\text { Keuangan } \\
\text { Daerah }\end{array}$ & & 3,301 & $\begin{array}{c}\text { Tidak terjadi } \\
\text { multikolinieritas }\end{array}$ \\
& & & \\
\hline
\end{tabular}

Sumber: Data Primer yang Diolah, 2017

Tabel di atas menunjukkan bahwa semua variabel independen mempunyai nilai Tolerance $\geq 0,10$ dan Variance Inflation Factor (VIF) $\leq 10$. Jadi, dapat disimpulkan bahwa pada penelitian ini tidak ada multikolinieritas antar variabel dalam model regresi.

Uji heteroskedastisitas bertujuan untuk menguji apakah dalam model regresi terjadi ketidaksamaan varians dari residual satu pengamatan ke pengamatan lain. Hasil uji heteroskedastisitas pada penelitian ini dapat dilihat pada tabel berikut

Tabel 5.Hasil Uji Heteroskedastisitas

\begin{tabular}{|c|c|c|c|}
\hline Variabel & Sig. & $\begin{array}{c}\text { Bata } \\
\text { s }\end{array}$ & Keterangan \\
\hline $\begin{array}{c}\text { Kompetensi } \\
\text { Sumber } \\
\text { Daya } \\
\text { Manusia }\end{array}$ & $\begin{array}{c}0,09 \\
3\end{array}$ & 0,05 & $\begin{array}{c}\text { Tidak terjadi } \\
\text { Heteroskedastisit } \\
\text { as }\end{array}$ \\
\hline $\begin{array}{c}\text { Penerapan } \\
\text { Standar } \\
\text { Akuntansi } \\
\text { Pemerintah } \\
\text { an }\end{array}$ & $\begin{array}{c}0,47 \\
8\end{array}$ & 0,05 & $\begin{array}{c}\text { Tidak terjadi } \\
\text { Heteroskedastisit } \\
\text { as }\end{array}$ \\
\hline $\begin{array}{c}\text { Penerapan } \\
\text { Sistem } \\
\text { Akuntansi } \\
\text { Keuangan } \\
\text { Daerah }\end{array}$ & $\begin{array}{c}0,93 \\
7\end{array}$ & 0,05 & $\begin{array}{c}\text { Tidak terjadi } \\
\text { Heteroskedastisit } \\
\text { as }\end{array}$ \\
\hline
\end{tabular}

Sumber: Data Primer yang Diolah, 2017

\section{Uji Hipotesis}

Penelitian ini menggunakan uji hipotesis dengan analisis regresi linear sederhana dan analisis regresi linear berganda. Analisis regresi linier sederhana digunakan untuk menguji pengaruh suatu variabel bebas terhadap variabel terikat. Oleh karena itu, analisis regresi linear sederhana digunakan menguji hipotesis pertama, hipotesis kedua, dan hipotesis ketiga. Hasil dari uji regresi sederhana adalah sebagai berikut : 


\section{JURNAL NOMINAL / VOLUME VI NOMOR 2 / TAHUN 2017}

Tabel 6.Hasil Uji Regresi Linier Sederhana

\begin{tabular}{cccccc}
\hline $\begin{array}{c}\text { Hipote } \\
\text { sis }\end{array}$ & $\begin{array}{c}\text { Cons } \\
\text { t. }\end{array}$ & $\begin{array}{c}\text { Koe } \\
\text { f. }\end{array}$ & $\mathbf{r}^{2}{ }_{\text {xy }}$ & $\begin{array}{c}\mathbf{t} \\
\text { hitung }\end{array}$ & $\begin{array}{c}\mathbf{t} \\
\text { tabel }\end{array}$ \\
\hline H1 & 10,94 & 0,24 & 0,388 & 8,049 & 1,667 \\
& 8 & 6 & & & \\
\hline H2 & $\begin{array}{c}12,18 \\
9\end{array}$ & $\begin{array}{c}0,20 \\
6\end{array}$ & 0,265 & 6,071 & 1,667 \\
\hline H3 & $\begin{array}{c}12,07 \\
\end{array}$ & $\begin{array}{c}0,22 \\
7\end{array}$ & 0,258 & 5,949 & 1,667 \\
& 6 & & & \\
\hline
\end{tabular}

Sumber: Data Primer yang Diolah, 2017

Berdasarkan tabel 6, dapat diketahui bahwa variabel Pengendalian Internal $\left(\mathrm{X}_{1}\right)$ pada Hipotesis I memiliki persamaan garis regresi sebagai berikut:

$$
Y=10,948+0,246 X_{1}
$$

Persamaan yang telah dibuat tersebut menunjukkan jika Kompetensi Sumber Daya Manusia $\left(\mathrm{X}_{1}\right)$ dianggap konstan, perubahan Kualitas Laporan Keungan Pemerintah Daerah adalah sebesar 10,948. Dari persamaan di atas juga dapat diketahui jika variabel Kompetensi Sumber Daya Manusia naik sebesar satu satuan, maka akan meningkatkan nilai variabel Kualitas Laporan Keungan Pemerintah Daerah sebesar 0,246 satuan. Nilai koefisien determinasi $\left(r_{x_{1} y}^{2}=0,388\right)$ pada hasil uji hipotesis menunjukkan nilai positif. Dengan demikian, dapat disimpulkan variabel Kompetensi Sumber Daya Manusia berpengaruh positif terhadap Kualitas Laporan Keuangan Pemerintah Daerah. Semakin tinggi Kompetensi Sumber Daya Manusia, maka akan semakin baik pula Kualitas Laporan Keuangan Pemerintah Daerah. Nilai koefisien determinasi sebesar 0,388, menunjukkan bahwa Kualitas Laporan Keuangan
Pemerintah Daerah yang dapat dijelaskan oleh variabel Kompetensi Sumber Daya Manusia adalah sebesar $38,8 \%$. Nilai t hitung $>\mathrm{t}$ tabel $(8,049>1,667)$ mengindikasi bahwa terdapat pengaruh yang positif antara Kompetensi Sumber Daya Manusia terhadap Kualitas Laporan Keuangan Pemerintah Daerah, maka hipotesis I diterima.

Variabel Penerapan Standar Akuntansi Pemerintahan $\left(\mathrm{X}_{2}\right)$ pada Hipotesis II memiliki persamaan garis regresi sebagai berikut:

$$
Y=12,189+0,206 X_{2}
$$

Persamaan yang telah dibuat tersebut menunjukkan jika Penerapan Standar Akuntansi Pemerintahan $\left(\mathrm{X}_{2}\right)$ dianggap konstan, perubahan variabel Kualitas Laporan Keuangan Daerah adalah sebesar 12,189. Dari persamaan di atas juga dapat diketahui jika variabel Penerapan Standar Akuntansi Pemerintahan naik sebesar satu satuan, maka akan meningkatkan nilai Kualitas Laporan Keuangan Pemerintah Daerah sebesar 0,206 satuan. Nilai koefisien determinasi $\left(r^{2} x_{2} y=0,265\right)$ pada hasil uji hipotesis menunjukkan nilai positif. Dengan demikian, dapat disimpulkan variabel Penerapan Standar Akuntansi Pemerintahan berpengaruh positif terhadap variabel Kualitas Laporan Keuangan Pemerintah Daerah. Semakin baik dalam menerapkan Standar Akuntansi Pemerintahan maka akan semakin baik pula Kualitas Laporan Keuangan Pemerintah 


\section{JURNAL NOMINAL / VOLUME VI NOMOR 2 / TAHUN 2017}

Daerah. Nilai koefisien determinasi sebesar 0,265 menunjukkan bahwa Kualitas Laporan Keuangan Pemerintah Daerah yang dapat dijelaskan oleh variabel Penerapan Standar Akuntansi Pemerintahan adalah sebesar $26,5 \%$. Nilai $\mathrm{t}$ hitung $>\mathrm{t}$ tabel $(6,071>1,667)$ mengindikasi bahwa terdapat pengaruh yang positif antara Penerapan Standar Akuntansi Pemerintahan terhadap Kualitas Laporan Keuangan Pemerintah Daerah, maka hipotesis II diterima.

Variabel Penerapan Sistem Akuntansi Keuangan Daerah $\left(\mathrm{X}_{3}\right)$ pada Hipotesis III memiliki persamaan garis regresi sebagai berikut:

$$
Y=12,077+0,226 X_{3}
$$

Persamaan yang telah dibuat tersebut menunjukkan jika Penerapan Sistem Akuntansi Keuangan Daerah $\left(\mathrm{X}_{3}\right)$ dianggap konstan, perubahan variabel Kualitas Laporan Keuangan Pemerintah Daerah adalah sebesar 12,077. Dari persamaan di atas juga dapat diketahui jika variabel Penerapan Sistem Akuntansi Keuangan Daerah naik sebesar satu satuan, maka akan meningkatkan nilai variabel Kualitas Laporan Keuangan Pemerintah Daerah sebesar 0,226 satuan. Nilai koefisien determinasi $\left(\mathrm{r}_{\mathrm{x}_{3} \mathrm{y}}^{2}=0,258\right)$ pada uji hipotesis menunjukkan nilai positif. Dengan demikian, dapat disimpulkan variabel Penerapan Sistem Akuntansi Keuangan Daerah berpengaruh positif terhadap variabel Kualitas Laporan
Keuangan Pemerintah Daerah. Semakin baik dalam menerapkan Sistem Akuntansi Keuangan Daerah maka akan semakin baik pula Kualitas Laporan Keuangan Pemerintah Daerah. Nilai koefisien determinasi sebesar 0,258, menunjukkan bahwa Kualitas Laporan Keuangan Pemerintah Daerah yang dapat dijelaskan oleh variabel Penerapan Sistem Akuntansi Keuangan Daerah adalah sebesar 25,8\%. Nilai $t$ hitung > t tabel $(5,949>1,667)$ mengindikasi bahwa terdapat pengaruh yang positif antara Penerapan Sistem Akuntansi Keuangan Daerah terhadap Kualitas Laporan Keuangan Pemerintah Daerah, maka hipotesis III diterima.

Hasil pengujian analisis regresi berganda untuk uji hipotesis IV dapat dilihat pada tabel 7 sebagai berikut:

\begin{tabular}{|c|c|c|c|c|c|}
\hline $\begin{array}{c}\text { Variabe } \\
1\end{array}$ & $\begin{array}{l}\text { Koefisi } \\
\text { en } \\
\text { Regresi }\end{array}$ & $\mathbf{R}$ & $\mathbf{R}^{2}$ & $\begin{array}{c}\text { F } \\
\text { hitu } \\
\text { ng }\end{array}$ & $\begin{array}{c}\text { F } \\
\text { tab } \\
\text { el }\end{array}$ \\
\hline $\begin{array}{l}\text { Konsta } \\
\text { nta }\end{array}$ & 7,886 & $\begin{array}{c}0,64 \\
0\end{array}$ & $\begin{array}{c}0,41 \\
0\end{array}$ & $\begin{array}{c}23,1 \\
33\end{array}$ & $\begin{array}{l}2,7 \\
0\end{array}$ \\
\hline KSDM & 0,198 & & & & \\
\hline PSAP & 0,005 & & & & \\
\hline PSAKD & 0,080 & & & & \\
\hline
\end{tabular}

Sumber: Data Primer yang Diolah, 2017

Berdasarkan tabel 7 dapat diketahui bahwa variabel Kompetensi Sumber Daya Manusia, Penerapan Standar Akuntansi Pemerintahan, Penerapan Sistem Akuntansi Keuangan Daerah secara bersama-sama, memiiki persamaan garis regresi sebagai berikut: 
JURNAL NOMINAL / VOLUME VI NOMOR 2 / TAHUN 2017

$Y=7,886+0,198 X_{1}+0,005 X_{2}+0,080 X_{3}$

Persamaan tersebut memiliki arti bahwa nilai koefisien Kompetensi Sumber Daya Manusia, dan Penerapan Standar Akuntansi Pemerintahan, Penerapan Sistem Akuntansi Keuangan Daerah mempunyai nilai positif, yang memiliki interpretasi bahwa semakin tinggi Kompetensi Sumber Daya Manusia dan semakin baik Penerapan Standar Akuntansi Pemerintahan serta Penerapan Sistem Akuntansi Keuangan Daerah maka semakin baik pula tingkat Kualitas Laporan Keuangan Pemerintah Daerah. Besar pengaruh Kompetensi Sumber Daya Manusia, Penerapan Standar Akuntansi Pemerintahan, dan Penerapan Sistem Akuntansi Keuangan Daerah secara simultan terhadap Kualitas Laporan Keuangan Pemerintah Daerah Provinsi DIY ditunjukkan oleh nilai $R^{2} y\left(x_{1}, x_{2}, x_{3}\right)$ sebesar 0,410. Artinya, $41 \%$ Kualitas Laporan Keuangan Pemerintah Daerah Provinsi DIY dipengaruhi oleh Kompetensi Sumber Daya Manusia, Penerapan Standar Akuntansi Pemerintahan, Penerapan Sistem Akuntansi Keuangan Daerah. Hipotesis keempat pada penelitian ini menyatakan terdapat pengaruh positif Kompetensi Sumber Daya Manusia, Penerapan Standar Akuntansi Pemerintahan, dan Penerapan Sistem Akuntansi Keuangan Daerah terhadap Kualitas Laporan Keuangan Pemerintah Daerah Provinsi DIY diterima karena
Kompetensi Sumber Daya Manusia, Penerapan Standar Akuntansi Pemerintahan, dan Penerapan Sistem Akuntansi Keuangan Daerah mempunyai nilai $\mathrm{F}$ hitung sebesar 23,133 dimana lebih besar dari $\mathrm{F}$ tabel yaitu sebesar 2,70.

\section{Pembahasan}

1. Pengaruh Kompetensi Sumber Daya Manusia terhadap Kualitas Laporan Keuangan Pemerintah Daerah Provinsi DIY

Hasil penelitian ini mendukung hipotesis pertama yang menyatakan bahwa Kompetensi Sumber Daya Manusia berpengaruh positif terhadap Kualitas Laporan Keuangan Pemerintah Daerah Provinsi DIY. Berdasarkan hasil pengujian hipotesis pertama, dapat ditulis persamaan regresi $\mathrm{Y}=10,948+0,246 \mathrm{X} 1$. Persamaan tersebut memiliki arti bahwa nilai koefisien Kompetensi Sumber Daya Manusia mempunyai nilai positif. Nilai koefisien korelasi juga menunjukkan nilai positif yaitu sebesar 0,623. Nilai koefisien determinasi sebesar 0,388 yang memiliki interpretasi bahwa $38,8 \%$ variabel dependen Kualitas Laporan Keuangan Pemerintah Daerah Provinsi DIY dipengaruhi oleh variabel independen Kompetensi Sumber Daya Manusia. Hal ini menunjukkan bahwa semakin baik Kompetensi Sumber Daya Manusia maka semakin baik Kualitas Laporan Keuangan Pemerintah Daerah. Hal tersebut dapat 
JURNAL NOMINAL / VOLUME VI NOMOR 2 / TAHUN 2017

dibuktikan dengan t hitung sebesar 8,049

dimana lebih besar dari t tabel yaitu sebesar 1,667 .

Kompetensi Sumber Daya Manusia merupakan kemampuan yang dimiliki seorang pegawai yang berhubungan dengan pengetahuan, ketrampilan, dan sikap dalam menyelesaikan kinerjanya sehingga dapat mencapai tujuan yang diinginkan. Sumber daya manusia yang memiliki kompetensi akan dapat menyelesaikan pekerjaanya secara efisien dan efektif. Adanya kompetensi sumber daya manusia maka akan mendukung ketepatan waktu pembuatan laporan keuangan.

2. Penerapan Standar Akuntansi Pemerintahan terhadap Kualitas Laporan Keuangan Pemerintah Daerah Provinsi DIY

Hasil penelitian ini mendukung hipotesis kedua yang menyatakan bahwa Penerapan Standar Akuntansi Pemerintahan berpengaruh positif terhadap Kualitas Laporan Keuangan Pemerintah Daerah Provinsi DIY. Berdasarkan hasil pengujian hipotesis kedua, dapat ditulis persamaan regresi $Y=12,189+0,206 X 2$. Persamaan tersebut memiliki arti bahwa nilai koefisien Penerapan Standar Akuntansi Pemerintahan mempunyai nilai positif. Nilai koefisien korelasi juga menunjukkan nilai positif yaitu sebesar 0,515. Nilai koefisien determinasi sebesar 0,265 yang memiliki interpretasi bahwa $26,5 \%$ variabel dependen Kualitas Laporan Keuangan Pemerintah Daerah Provinsi DIY dipengaruhi oleh variabel independen Penerapan Standar Akuntansi PemerintahanHal tersebut dapat dibuktikan dengan thitung sebesar 6,071 dimana lebih besar dari t tabel yaitu sebesar 1,667. Hal ini menunjukkan bahwa semakin baik Penerapan Standar Akuntansi Pemerintahan maka semakin baik kualitas laporan keuangan.

Standar Akuntansi Pemerintahan merupakan pedoman penyajian laporan keuangan. Pemerintah daerah mempunyai kewajiban untuk menyajikan laporan keuangan sebagai bentuk tanggung jawabnya terhadap pengelolaan keuangan. Laporan keuangan yang dibuat harus memuat unsur-unsur yang telah diatur dalam standar akuntansi pemerintahan. Berdasarkan Peraturan Pemerintah No. 71 tahun $2010 \quad$ Standar Akuntansi Pemerintahan di Indonesia adalah berbasis akrual. Basis akrual berarti mengakui dan mencatat peristiwa ekonomi serta melaporkan pada saat transaksi atau peristiwa ekonomi itu terjadi. Penerapan basis akrual diharapkan dapar memperlihatkan akuntabilitas penggunaan sumber daya ekonomi. 


\section{JURNAL NOMINAL / VOLUME VI NOMOR 2 / TAHUN 2017}

3. Penerapan Sistem Akuntansi

Keuangan Daerah terhadap Kualitas

Laporan Keuangan Pemerintah

Daerah Provinsi DIY

Hasil penelitian ini mendukung hipotesis ketiga yang menyatakan bahwa kompetensi sumber daya manusia berpengaruh positif terhadap kualitas laporan keuangan. Berdasarkan hasil pengujian hipotesis ketiga, dapat ditulis persamaan regresi $\mathrm{Y}=12,077+0,226 \mathrm{X}_{3}$. Persamaan tersebut memiliki arti bahwa nilai koefisien Penerapan Sistem Akuntansi Keuangan Daerah mempunyai nilai positif. Nilai koefisien korelasi juga menunjukkan nilai positif yaitu sebesar 0,508. Nilai koefisien determinasi sebesar 0,258 yang memiliki interpretasi bahwa $25,8 \%$ variabel dependen Kualitas Laporan Keuangan Pemerintah Daerah Provinsi DIY dipengaruhi oleh variabel independen Penerapan Sistem Akuntansi Keuangan Daerah. Hal tersebut dapat dibuktikan dengan t hitung sebesar 5,949 dimana lebih besar dari t tabel yaitu sebesar 1,667. Hal ini menunjukkan bahwa semakin baik dalam menerapkan Sistem Akuntansi Keuangan Daerah maka semakin baik Kualitas Laporan Keuangan Pemerintah Daerah.

Suatu informasi yang disajikan membutuhkan sebuah sistem dalam penyusunannya. Sistem Akuntansi Daerah adalah rangkaian prosedur yang dilakukan mulai dari mengumpulkan, mencatat, menggolongkan, dan meringkas serta melaporkan transaksi. Penerapan sistem akuntansi keuangan daerah diperlukan untuk menghasilkan keluaran berupa laporan keuangan pemerintah daerah yang tepat dan akurat. Laporan keuangan daerah yang akurat menjadi dasar untuk pengambilan keputusan. Oleh karena itu, laporan keuangan pemerintah daerah harus berkualitas. Jadi, untuk memperoleh kualitas laporan keuangan daerah sesuai Standar Akuntansi Pemerintahan harus melalui Penerapan Sistem Akuntansi Keuangan Daerah.

4. Kompetensi Sumber Daya Manusia, Penerapan Standar Akuntansi Pemerintahan, Penerapan Sistem Akuntansi Keuangan Daerah secara bersama-sama terhadap Kualitas Laporan Keuangan Pemerintah Daerah Provinsi DIY

Hasil penelitian ini mendukung hipotesis keempat yang diajukan yaitu bahwa Sumber Daya Manusia, Penerapan Standar Akuntansi Pemerintahan, Penerapan Sistem Akuntansi Keuangan Daerah secara bersama-sama berpengaruh terhadap Kualitas Laporan Keuangan Pemerintah Daerah Provinsi DIY. Pengujian terhadap hipotesis keempat menghasilkan persamaan regresi $\mathrm{Y}=7,886$ $+0,198 X_{1}+0,005 X_{2}+0,080 X_{3}$. Nilai $R_{y(1,2,3)}$ menunjukkan nilai positif yaitu 0,508. Besar pengaruh Kompetensi Sumber Daya Manusia, Penerapan Standar 


\section{JURNAL NOMINAL / VOLUME VI NOMOR 2 / TAHUN 2017}

Akuntansi Pemerintahan, dan Penerapan Sistem Akuntansi Keuangan Daerah secara simultan terhadap Kualitas Laporan Keuangan Pemerintah Daerah Provinsi DIY ditunjukkan oleh nilai $R^{2} y(1,2,3)$ sebesar 0,410. Artinya, 41\% Kualitas Laporan Keuangan Pemerintah Daerah Provinsi DIY dipengaruhi oleh Kompetensi Sumber Daya Manusia, Penerapan Standar Akuntansi Pemerintahan, Penerapan Sistem Akuntansi Keuangan Daerah. Nilai F hitung $(23,133)$ $>\mathrm{F}$ tabel $(2,70)$. Hal ini berarti bahwa semaki tinggi Kompetensi Sumber Daya Manusia Penerapan Standar Akuntansi Pemerintahan baik, dan Penerapan Sistem Akuntansi Keuangan Daerah dapat dipahami dan diimplementasikan dengan baik, maka Kualitas Laporan Keuangan Pemerintah Daerah yang dihasilkan akan semakin baik. Sebaliknya, apabila Kompetensi Sumber Daya Manusia rendah, Penerapan Standar Akuntansi Pemerintahan yang belum efektif, dan Penerapan Sistem Akuntansi Keuangan Daerah yang belum memenuhi kebijakan akuntansi dapat menimbulkan Kualitas Laporan Keuangan Pemerintah Daerah yang kurang baik.

\section{KESIMPULAN DAN SARAN}

\section{Kesimpulan}

Berdasarkan penjelasan dan analisis data yang telah dilakukan oleh peneliti terkait pengaruh Kompetensi Sumber Daya Manusia, Penerapan Standar Akuntansi Pemerintahan, dan Penerapan Sistem

Akuntansi Keuangan Daerah terhadap Kualitas Laporan Keuangan Pemerintah Daerah dapat ditarik beberapa kesimpulan. Pertama, Kompetensi Sumber Daya Manusia berpengaruh positif terhadap Kualitas Laporan Keuangan Pemerintah Daerah DIY. Hal ini dapat dibuktikan dengan persamaan regresi linier sederhana $\mathrm{Y}=10,948+0,26 \mathrm{X}_{1}$, koefisien determinasi $r_{x_{1} y=0,623} \quad r^{2} x_{1} y=0,388$, serta $t$ hitung $>t$ tabel $(8,049>1,66)$. Kedua, Penerapan Standar Akuntansi Pemerintahan berpengaruh positif terhadap terhadap Kualitas Laporan Keuangan Pemerintah Daerah DIY. Hal ini dapat dibuktikan dengan persamaan regresi linier $\mathrm{Y}=$ $12,189+0,206 X_{2}$, koefisien determinasi $r_{x_{2} y=0,515} \quad r^{2}{ }_{x_{2} y=0,265}$, serta $t$ hitung $>t$ tabel $(6,071>1,66)$. Ketiga, Penerapan Sistem Akuntansi Keuangan Daerah berpengaruh positif terhadap Kualitas Laporan Keuangan Pemerintah Daerah DIY. Hal ini dapat dibuktikan dengan persamaan regresi linier sederhana $\mathrm{Y}=$ $12,077+0,226 \mathrm{X}_{3}$, koefisien determinasi $r_{x_{3} y=0,508} \quad r_{x_{3} y=0,258}^{2}$, serta $t$ hitung $>t$ tabel $(5,949>1,66)$. Keempat, Kompetensi Sumber Daya Manusia, Penerapan Standar Akuntansi Pemerintahan, Penerapan Sistem Akuntansi Keuangan Daerah terhadap Kualitas Laporan Keuangan Pemerintah Daerah DIY. Hal ini dibuktikan dengan persamaan regresi linier berganda $\mathrm{Y}=$ $7,886+0,198 \mathrm{X}_{1}+0,005 \mathrm{X}_{2}+0,080 \mathrm{X}_{3}$, 


\section{JURNAL NOMINAL / VOLUME VI NOMOR 2 / TAHUN 2017}

koefisien

determinasi $R_{y(1,2,3)=0,640 \quad R^{2}(1,2,3)=0,410}$, serta $\mathrm{F}$ hitung $>\mathrm{F}$ tabel $(23,133>2,70)$.

\section{Saran}

Berdasarkan hasil penelitian dan dapat diusulkan saran yang diharapkan akan bermanfaat. Bagi Pemerintah Daerah DIY diharapkan dapat meningkatkan keandalan laporan keuangan karena menyajikan informasi laporan keuangan secara wajar dan tidak berpihak pada kebutuhan pihak tertentu bukan sebuah prestasi melainkan suatu kewajiban, meningkatkan kompetensi pegawai penatausaha keuangan dalam mengelola dan menyajikan laporan keuangan. Hal tersebut dapat dilihat dari masih adanya pegawai penatausaha keuangan yang memiliki keterampilan rendah dalam bidang akuntansi, mengevaluasi penerapan standar akuntansi pemerintahan terutama asset-aset yang belum jelas statusnya seperti beberapa bangunan Pemerintah Daerah DIY yang berdiri diatas Sultan Ground.

Bagi peneliti selanjutnya, sebaiknya dapat menambahkan variabel-variabel lain seperti Kapasitas Sumber Daya Manusia, Pengendalian Internal, Teknologi Informasi, SIMDA, SIPKD. Penelitian dapat disertai dengan metode wawancara atau terlibat tatap muka langsung dengan responden. Hal ini dilakukan dengan tujuan agar responden lebih memahami pernyataan kuesioner yang diberikan oleh peneliti, sehingga hasil yang diperoleh lebih akurat

\section{DAFTAR PUSTAKA}

Abdul Halim. (2007). Akuntansi Keuangan Daerah. Jakarta : Salemba Empat

Angga Dwi Permadi. (2013). Pengaruh Sistem Akuntansi Keuangan Pemerintah Daerah terhadap Kualitas Laporan Keuangan Pemerintah Daerah Studi Kasus pada Dinas Bina Marga Kota Bandung. Skripsi Universitas Widyatama Bandung.

Bastian, Indra. (2007). Sistem Akuntansi Sektor Publik. Jakarta : Salemba Empat

(2010). Akuntansi Sektor Publik Suatu Pengantar. Jakarta : Erlangga

BPK RI. (2016). Ikhtisar Hasil Pemeriksaan Semester 1 Tahun 2016. Diakses pada 22 Desember 2016. http://www.bpk.go.id/ihps

Departemen Pendidikan Nasional Balai Pustaka. (1989). Kamus Besar Bahasa Indonesia. Jakarta : Balai Pustaka.

Devi Rovieyanti. (2012). Pengaruh Kompetensi Sumber Daya Manusia dan Penerapan Sistem Akuntansi Keuangan Daerah terhadap Kualitas Laporan Keuangan Daerah (Survei pada Organisasi Perangkat Daerah (OPD) Kabupaten Tasikmalaya. Journal Accounting Vol 1 No.1.

Erma Setiawati. (2014). Kualitas Pelaporan Keuangan Pemerintah Daerah Ditinjau Dari Sumber Daya Manusia, Pengendalian Intern, Pemanfaatan Teknologi Informasi Dan Pemahaman Akuntansi. Call for paper Universitas 
JURNAL NOMINAL / VOLUME VI NOMOR 2 / TAHUN 2017

Muhammadiyah Surakarta. Diambil pada 1 November 2015, darihttp://publikasiilmiah.ums.ac.id

Husein Umar. (2011). Metode Penelitian untuk Skripsi dan Tesis Bisnis. Jakarta: Rajawali Pers.

Imam Ghozali. (2011). Aplikasi Analisis Multivariate dengan Program IBM SPSS 19 Edisi 5. Semarang: Universitas Diponegoro.

Kadek Desiana Wati, Nyoman Trisna Herawati, dan Ni Kadek Sinarwati. (2014). "Pengaruh Kompetensi SDM, Penerapan SAP, dan Sistem Akuntansi Keuangan Daerah terhadap Kualitas Laporan Keuangan Daerah". E-Journal S1 Ak Universitas Pendidikan Ganesha Vol 2 No. 1.

Keputusan Kepala Badan Kepegawaian Negara No 46A Tahun 2007. Pedoman Penyusunan Standar Kompetensi Jabatan Struktural Pegawai Negeri Sipil. Diakses pada 1 November 2015, dari http:/mahsanafifiles.wordpress.com

Mardiasmo. (2006). Perwujudan Transparansi dan Akuntabilitas Publik melalui Akuntansi Sektor Publik: Suatu Sarana Good Governance. Jurnal Akuntansi Pemerintah Vol 2. No. 1

Mulyadi. (2007). Sistem Akuntansi. Jakarta: Salemba Empat

Nawawi. (2001). Manajemen Sumber Daya Manusia untuk Bisnis yang Kompetitif. Yogyakarta : Gajah Mada University Press

Permendagri No. 4 Tahun 2008. Pedoman Pelaksanaan Reviu atas Laporan Keuangan Pemerintah Daerah. Diakses pada 1 November 2015, darihttp://keuda.kemendagri.go.id
Permendagri No. 13 Tahun 2006. Pedoman Pengelolaan Keuangan Daerah. Diakses pada 1 November 2015, darihttp://portal.mahkamahko nstitusi.go.id

PP No. 71 Tahun 2010. Diakses pada 1 November 2015, dari http://www.djpk.depkeu.go.id

Pramono Hariadi, dkk. (2010). Pengelolaan Keuangan Daerah. Jakarta :Salemba Empat

Republik Indonesia. (2010). Standar Akuntansi Pemerintahan. Jakarta : Salemba Empat

Rivai, Veithzal. (2011). Manajemen Sumber Daya Manusia untuk Perusahaan. Jakarta: Rajawali pers.

Sugiyono. (2008). Statistika Untuk Penelitian. Bandung: Alfabeta. .(2011). Metode Penelitian Kombinasi (Mixed Methods). Bandung : Alfabeta

Sutrisno Hadi. (2004). Analisis Regresi. Yogyakarta: Andi Offset

Vicky Agustiawan Lasoma. (2012). "Pengaruh Standar Akuntansi Pemerintah (SAP) terhadap Kualitas Laporan Keuangan Pemerintah Daerah pada Dinas Pendapatan Dan Pengelolaan Keuangan Dan Aset Daerah Kabupaten Gorontalo Utara". Jurnal Akuntansi Vol. 2. No.1

Yadiati, Winwin dan Abdullah Mubarok. (2017). Kualitas Pelaporan Keuangan. Jakarta: Kencana Prenadamedia Group 